\title{
PDZ and LIM Domain Protein 3
}

National Cancer Institute

\section{Source}

National Cancer Institute. PDZ and LIM Domain Protein 3. NCI Thesaurus. Code

C118550.

PDZ and LIM domain protein 3 (364 aa, $39 \mathrm{kDa}$ ) is encoded by the human PDLIM3 gene.

This protein may be involved in the arrangement of the actin cytoskeleton. 